\title{
Mussel shell mulch can increase vineyard sustainability by changing scarab pest behaviour
}

\author{
Mauricio González-Chang ${ }^{1}$ (D) - Stéphane Boyer ${ }^{2,3}$ • Glen L. Creasy ${ }^{4}$. \\ Marie-Caroline Lefort ${ }^{1,2} \cdot$ Stephen D. Wratten ${ }^{1}$
}

Accepted: 23 August 2017 / Published online: 15 September 2017

(C) INRA and Springer-Verlag France SAS 2017

\begin{abstract}
Global concern about external costs of pesticides (environment and human health) has promoted the development of new strategies for pest control in agro-ecosystems. In this sense, mineral-based dust and optical barriers have been used against agricultural pests in a variety of crops worldwide as alternatives to orthodox pest control. Recently, mussel shells' optical properties have been investigated, suggesting their potential role in pest control as an optical barrier. In the present study, the effects of hydrophobic particle films, diatomaceous earths and mussel shells were evaluated for their potential in reducing the endemic New Zealand scarab Costelytra zealandica damage in vineyards. Feeding deterrents significantly reduced its damage by $46 \%$ when applied to Pinot Noir vines. In addition, vines treated with mussel shells had $69 \%$ fewer beetles on them. When hydrophobic particle films and mussel shells were evaluated in the same experiment, 33 and $73 \%$ reduction in damage was achieved by these two treatments, respectively. Furthermore, the addition of mussel shells increased grape yield by $28 \%$. Here we demonstrate that mussel shells applied in the under-vine areas altered the flying and landing behaviour of a melolonthine pest. This is the first reported example of "waste" mollusc shells changing insect pest behaviour, highlighting their potential use in sustainable pest control
\end{abstract}

Mauricio González-Chang

mauriciogonzalezchang@gmail.com

1 Bio-Protection Research Centre, Lincoln University, PO Box 85084, Lincoln 7647, New Zealand

2 Insect Biology Research Institute (IRBI), Université François-Rabelais de Tours, 37200 Tours, Parc Grandmont, France

3 Environmental and Animal Sciences, Unitec Institute of Technology, Auckland 1025, New Zealand

4 Centre for Viticulture and Oenology, Lincoln University, Lincoln 7647, New Zealand programmes. Therefore, this approach might contribute to reducing the damage caused by other Scarabaeidae beetles with similar flight behaviour around the world.

Keywords Natural deterrents $\cdot$ Sustainable management · Seafood waste recycle $\cdot$ Video analysis $\cdot$ Melolonthinae

\section{Introduction}

In recent years, increasing attention has been paid to the negative effects that synthetic-derived pesticides have on environmental quality, pest resistance and human health. Recent advances in pest management have suggested the use of more ecologically based approaches, including modifying insect behaviour, as an important tool for sustainable pest management (Foster and Harris 1997; Gurr et al. 2017). These behavioural changes usually involve alteration of insects' visual and/or olfactory perception of its environment (Foster and Harris 1997; Gurr et al. 2017). Although pest management has historically involved the use of olfactory behavioural disruptors, such as pheromones, the application of different coloured reflective surfaces has also been studied to some extent to investigate behavioural changes mediated by the modification of insects' visual perception of its host (Prokopy and Owens 1983). For aphid pests, reflective mulches placed on the ground have been used to reduce the damage caused by several species, with important consequences for the reduction of insect-borne viruses on a range of crops worldwide (Antignus 2014). Despite these benefits, the dramatic increase in the use of plastic reflective materials in agro-ecosystems during the last 10 years has raised major agronomic, economic and environmental concerns related to their removal and disposal (Kasirajan and Ngouajio 2012). A potential environmentally friendly alternative to this problem 
could involve the use of biodegradable "waste" materials such as mussel shells. Studies in vineyards have shown that when mussel shells are placed in the under-vine areas, shortwavelength light (ultraviolet-B, 280-320 nm) is reflected to the vine canopy (Sandler et al. 2009; Creasy and Ross 2010). Therefore, it is plausible that the shells' reflective properties might deter insect landing behaviour through an "optical barrier", as described before for other insect species (Prokopy and Owens 1983; Foster and Harris 1997). However, mussel shells have never been evaluated as a control strategy to reduce insect landing in crops. Here, we deploy mussel shells (Perna canaliculus Gmelin) as a potential landing deterrent to adult grass grub beetles (Costelytra zealandica White), which in New Zealand invade different horticultural crops and cause severe economic damage.

\subsection{Feeding deterrents}

Feeding deterrents, such as hydrophobic particle films and diatomaceous earths can also change insects' behaviour, offering a natural approach for pest control (Glenn et al. 1999; Korunic 2013). The former is a product made of kaolin clays (kaolinite) bounded to a synthetic hydrocarbon that makes the clay hydrophobic (Glenn et al. 1999), and therefore less affected by rainy conditions when applied for pest control in the field (Glenn and Puterka 2005). This approach has been used against several pest species on a range of crops over the last 15 years, including coleopterans (Showler 2002; Silva and Ramalho 2013). Unlike hydrophobic particle films, diatomaceous earths are silica-derived particles from ancient diatom shells that settled in the bottom of the ocean after they died, between 20 and 80 million years ago (Korunic 1998). In contrast to hydrophobic particle films, diatomaceous earths are easily removed from treated plants by rainy conditions, and for this reason, they have been extensively investigated to protect stored agricultural products against several coleopteran species (Athanassiou et al. 2011; Korunic 2013). However, diatomaceous earths have been recently used under field conditions in combination with hydrophobic particle films to reduce oviposition and nymph numbers of the vine cicada Psalmocharias alhageos Kolenati (Homoptera: Cicadidae) (Valizadeh et al. 2013). The latter study suggests that potential additive effects on pest control could be expected when hydrophobic particle films and diatomaceous earths are combined in field conditions.

\subsection{Scarabeid pest in New Zealand vineyards}

In New Zealand vineyards, adults of the endemic beetle C. zealandica White (Scarabaeidae: Melolonthinae: Liparetrini) can cause severe vine defoliation (Fig. 1). At dusk, between October and November, $C$. zealandica adults flight activity last for approximately 25 min (González-Chang
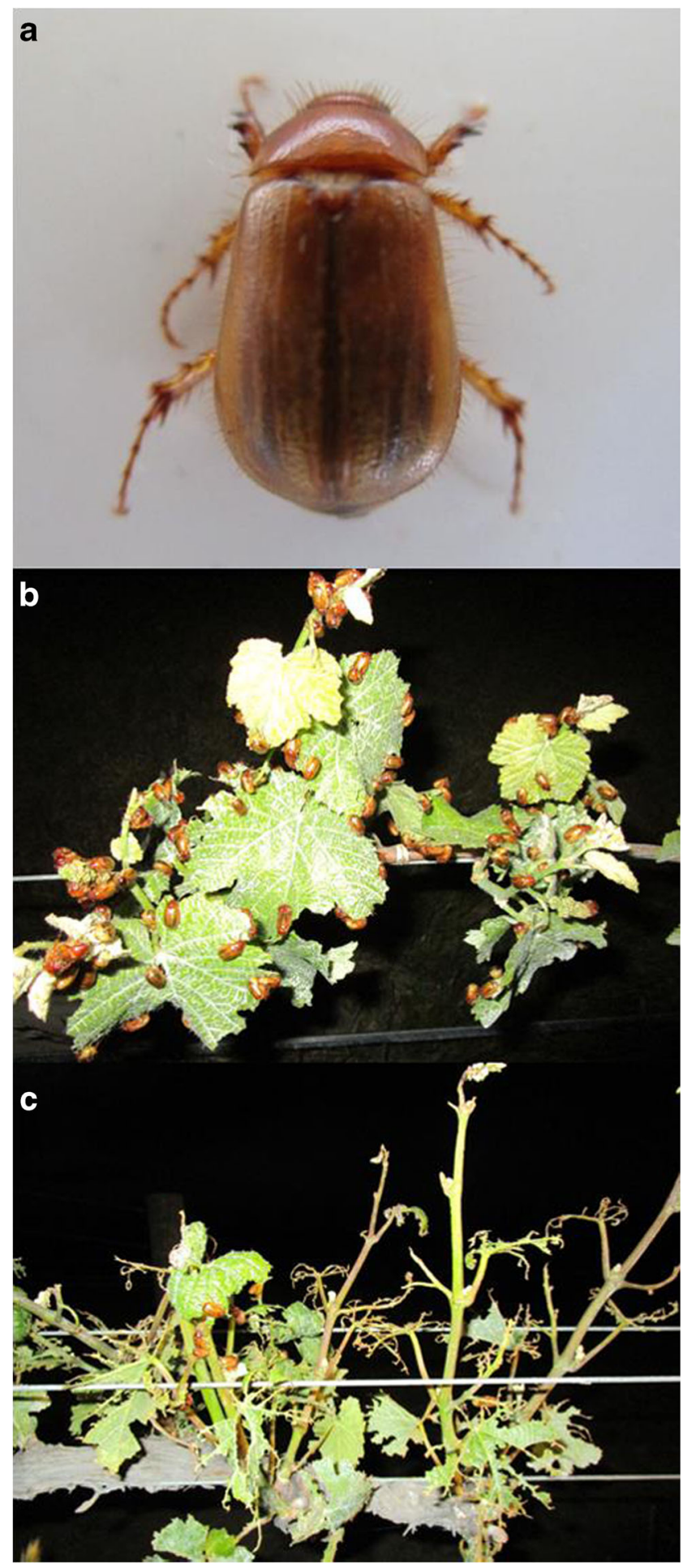

Fig. 1 a Adult $C$. zealandica beetle (adult size $13 \mathrm{~mm}$ ). b In the study area, beetles' flight season starts from late October until late November. During the early stages of beetle invasion, feeding does not occur. c As the flight season advances, beetles consume the vines leaves, producing in some cases severe defoliation (photos by M.G. Chang)

et al. 2017), with their flying directed towards plant silhouettes to where they land, feed and mate (Farrell and Wightman 1972). After a short period on the plants, they drop to the 
ground and lay eggs (Farrell and Wightman 1972). As a consequence of this ephemeral presence on vine foliage, at both daily and monthly time scales, the prophylactic use of contact synthetic insecticides, such as pyrethroids, have dominated the vineyard management spectrum to control this pest since early 1990. Considering C. zealandica flying and landing behaviour, in addition to the current non-sustainable reliance on synthetic pesticides, the use of hydrophobic particle films, diatomaceous earths and mussel shells could offer an ecologically friendly alternative to reduce adult $C$. zealandica damage in vineyards. Therefore, the aims of this work were (i) to evaluate the contribution of hydrophobic particle films, diatomaceous earths and mussel shells to reducing the damage caused by $C$. zealandica adults on vine plants; (ii) to analyse the impact of hydrophobic particle films and mussel shells on grape yield; and (ii) to quantify the effects of mussel shells on adult $C$. zealandica behaviour.

\section{Material and methods}

\subsection{Study sites}

The Marlborough region in New Zealand is well recognised as an important area for wine production. Within this region, severe vine defoliation caused by $C$. zealandica adults has been recorded (Fig. 1). Two Marlborough areas were selected to study alternative strategies to reduce adult $C$. zealandica damage in vineyards. In the Awatere Valley, one vineyard block (2.21 ha; Kono Beverages, $41^{\circ} 44^{\prime} \mathrm{S}, 173^{\circ} 52^{\prime} \mathrm{E}$; experiment 1) was used in spring 2014 to evaluate the effects of feeding deterrents and another block to evaluate the impact of crushed mussel shells (6.12 ha; Kono Beverages; experiment $2)$. These two experiments were established and evaluated separately. However, during spring 2015, hydrophobic particle films and mussel shells were combined in a third vineyard block belonging to another wine company close to Blenheim city (4.58 ha; Wither Hills, $41^{\circ} 33^{\prime} \mathrm{S}, 173^{\circ} 55^{\prime} \mathrm{E}$; experiment 3 ), to evaluate potential synergistic or additive effects. Vines were 14 and 15 years old in the Awatere Valley and Blenheim, respectively. At all locations, organically managed vineyards (cv. Pinot Noir) were used.

\subsection{Experimental designs}

\subsubsection{Experiment 1: feeding deterrents and beetle damage in vines}

Adult $C$. zealandica damage on vine leaves starts from their margin towards their centre, leaving the leaf veins untouched when severe cases of defoliation occur (Fig. 1). In the Awatere Valley (2014), four treatments were established in a randomised block design to test their efficacy to reduce adult
C. zealandica damage. These were as follows: hydrophobic particle films (Surround WP $\odot$, USA), diatomaceous earths (Redox Pty Ltd., NZ), a mixture of both (1:1) and a control. Each treatment was applied to five vines in each of two adjacent parallel rows (10 plants in total). Treatments were established along these two rows, next to each other. Unfortunately, separation between treatments was not possible along the row, due to spatial vineyard constraints. To alleviate this limitation to some extent, damage was measured only in the two central plants in each of those treated rows (four plants in total). Damaged leaves were identified and counted on each vine plant and then, expressed as the number of damaged leaves divided by the total number of leaves per plant. Damage assessment was performed at the end of the adults' flight season, in early December 2014. Overall, six replicates were established, each separated by $5 \mathrm{~m}$. The feeding deterrents were mixed with water and applied to the vine foliage using a 400-1 hydraulic vine sprayer (Silvan G3, Australia), three times before the adult flight activity peak for 2014 occurred, on October 30 and November 7 and 14 (González-Chang 2016). In this experiment, the treatments were applied three times, due to the rapid foliage growth that occurred during that period. The dose used was $20 \mathrm{~g} \mathrm{l}^{-1}$ at a rate of $4001 \mathrm{ha}^{-1}\left(8 \mathrm{~kg}\right.$ a.i. ha $\left.{ }^{-1}\right)$, as previously reported (Valizadeh et al. 2013). When hydrophobic particle films and diatomaceous earths were combined, $10 \mathrm{~g} \mathrm{l}^{-1}$ of each product was used to keep the $20 \mathrm{~g}^{-1}$ concentration constant amongst treatments.

\subsubsection{Experiment 2: mussel shells and adult numbers on treated vines}

In this work, a landing deterrent refers to a material that can reduce the number of insects that land on their host plant. Then, to evaluate the effect of mussel shells as a landing deterrent on beetle numbers on vine plants, these were applied to the under-vine areas in the Awatere Valley (2014). This experiment was established at the edge of the vineyard block, as it has been suggested that $C$. zealandica adults aggregate in this area (González-Chang 2016). For this reason, the first four plants at the end of 30 vine rows in the edge of a vineyard block were used. Treatments (mussel shells and control) were established in a randomised block design, with 15 replicates. On each mussel-shell-treated bay (a group of four vine plants along the row), $1.4 \mathrm{~m}^{3}$ of previously crushed mussel shells were evenly applied using a modified manure spreader (Millcreek, USA). This produced a 30-cm layer of mussel shells in the under-vine area. These shells were crushed at Kono Seafood factory (Blenheim, NZ), as a strategy to reduce the volume of disposed shells after the industrial mussel processing. The mean size of the crushed shells was approximately $7 \mathrm{~cm}^{2}$. C. zealandica adults were counted and then removed 
from vine leaves in treated and untreated rows between 21:30 and 23:00 on November 16, 2014.

\subsubsection{Experiment 3: additive effects of feeding and landing deterrents on beetle numbers and vine damage}

Based on the results obtained from the two experiments described above, the effect of mussel shells and hydrophobic particle films on beetle numbers, their damage on vine foliage and grape yield was investigated at Wither Hills. Damaged leaves were identified, counted and reported in this work exactly as described in experiment 1 . Damage assessment was carried out in early December 2015. Then, grape yield was measured as the weight of all grape bunches per plant $\left(\mathrm{kg} \mathrm{plant}{ }^{-1}\right.$ ), in early April 2016. An electronic portable balance was use for the latter (CAS SW series, Korea). Hydrophobic particle films, mussel shells, a combination of both (1:1) and a control were established in a randomised block design (Fig. 2a). Hydrophobic particle films was selected over diatomaceous earths as feeding deterrent for this experiment due to its hydrophobic nature (Glenn et al. 1999), but also because statistical differences were not found between both with regards to adult damage (see "Results and discussion"). Hydrophobic particle films was applied using a $20 \mathrm{~g} \mathrm{l}^{-1}$ concentration at a rate of $4001 \mathrm{ha}^{-1}$ only once, on November 1, 6 days before the adult flight peak of abundance for the 2015 season occurred (González-Chang 2016). All treatments were established in the edge of the vineyard block, using the first four plants at the end of 32 vine rows (Fig. 2a). Thus, as each treatment considered four vine plants, a total of 16 plants were used in each replicate. Overall, eight replicates were used, separated by $10 \mathrm{~m}$ from each other. In addition, the application of feeding and landing deterrents in the edge of the vineyard block allowed the investigation of potential effect of those treatments on adult $C$. zealandica distribution towards the centre of the block (Fig. 2b). Therefore, adults were collected along vine rows from the first bay in the edge to $30 \mathrm{~m}$ from it (Fig. 2b). In those selected bays, adults were counted on the vine foliage, and then removed by hand between 21:30 and 23:00 on November 16, 2015. On each treatment involving mussel shells, crushed shells were applied as described for experiment 2 .

\subsection{C. zealandica flight activity and behaviour}

At Wither Hills (2015), beetle activity was recorded on vines with and without mussel shells using the arrangement of experiment 3 (Fig. 2). Adult activity was measured using security surveillance infra-red-sensitive video cameras (Sanyo VCC-HD4600P, China). Two cameras were established at $50 \mathrm{~cm}$ in front of the first vine plant in a row; one on a bay treated with mussel shells and the other on control. Cameras were installed at $1.5 \mathrm{~m}$ over the ground

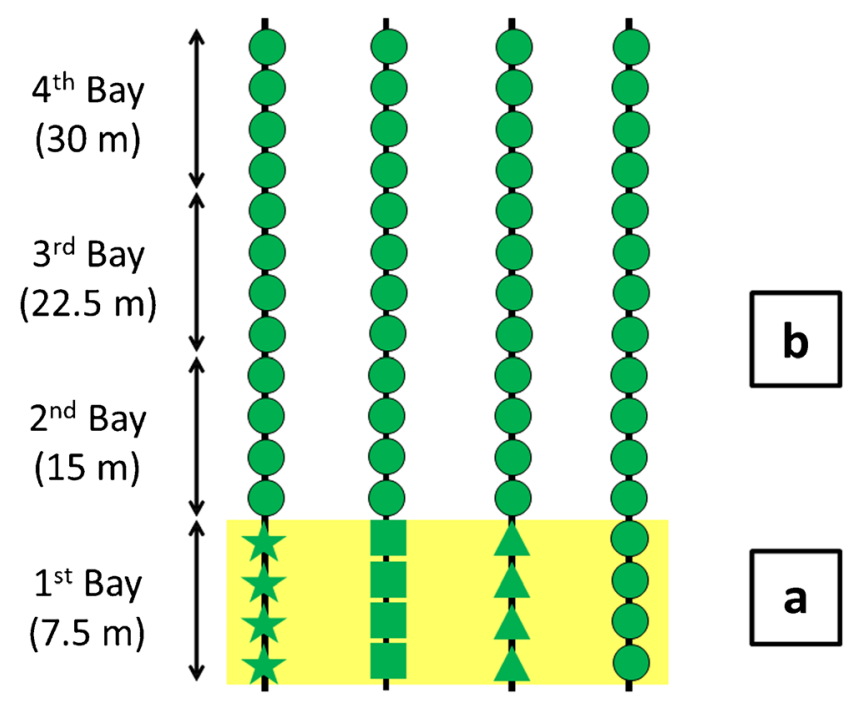

Fig. 2 Diagram that illustrates the spatial arrangement of one replicate in experiment 3. Overall, eight replicates were established at the end of the rows at Wither Hills vineyard during 2015, separated by $10 \mathrm{~m}$ from each other. Each green symbol represents one vine plant along a vine row. a Random distribution of mussel shells (triangle), hydrophobic particle films (square), both treatments combined (star) and control (circle). The distance of each bay (a group of four vine plants) from the edge of the block towards its centre is shown in brackets. b Spatial distribution of the second, third and fourth bays used to evaluate adult $C$. zealandica distribution when deterring treatments occurred at the first bay. Adult counts were taken from all four bays in each of the eight replicates used

using a tripod. Beetle activity around those two plants was recorded on five consecutive evenings, starting on November 6 until November 10, from 19:00 to 23:00. On each date, all videos were recorded using $1280 \times 720$ pixel resolution and encoded afterwards into MKV format (Matroska Video Codec) using VSDC free video editor software (Flash-Integro LLC, v.4.0.1.479). Each video was subsequently cut from the start to the end of adults' flight activity. Then, screenshots of those edited videos were taken every minute using VSDC software. On each screenshot, every white dot found was counted, as well as "shadow" dots that appeared on the plants. Each dot (shadow or white) represented one C. zealandica adult. These shadows were produced by adults flying in front of the infra-red light, projected over the white background produced by the vine plants. Due to the lack of image background contrast produced by the infra-red light over the vines, all white and shadow dots in the screenshots were counted manually. Through the analysis of the screenshots, two different behaviours were distinguished: (i) hovering or flying, in which each counted dot was over the vines, changing its position between two consecutive screenshots, and (ii) landing, where each counted dot was on the vines, without changing its position. The presence/absence of dots between screenshots was assessed by rapidly alternating between two consecutive screenshots in the computer screen, allowing for the identification of flying/hovering 
and/or landed beetles. These white dots and shadows were counted using the "cell counter" function within the software Fiji (Schindelin et al. 2012).

\subsection{Statistical analyses}

Data from experiments 1 and 3 (damage and yield) were pooled and averaged by replicate within their respective treatments to correct spatial pseudoreplication. Proportional data were corrected using a square root arcsine transformation to fulfil the necessary requirements for an analysis of variance. Yield data were homoscedastic and normally distributed; therefore, analysis of variance was also carried out. Normality and homoscedasticity were graphically checked for unusual patterns in residuals vs. fitted values and in residuals' distribution within a Q-Q plot (Zuur et al. 2009). A post hoc analysis was performed on damage and yield data using Tukey's honest significant difference test, calculated with the R package "multcomp". To evaluate the effect of mussel shells on the number of adults that landed on vines in 2014 and 2015 (experiment 2 and 3, respectively), count data were $\log _{10}$ transformed, and subsequently, a paired $t$ test was carried out between vineyard bays under different treatments.

Mean adult beetle activity data (beetle $\mathrm{min}^{-1}$ ) from the screenshot analysis was calculated for 5-min time periods. During the flight period recorded, six periods were created at $5,10,15,20,25$, and $30 \mathrm{~min}$ after adults began to fly. Such periods included data on mean beetle activity (flying/landing) during that period. Due to a lack of homoscedasticity in the data, they were transformed using a spread-stabilising power transformation within the R package "car". No autocorrelation was found between data from the five different recorded dates, so these were considered as replicates. Each time period was analysed independently, using a paired $t$ test between mussel shells and control treatments. Adult numbers along vine rows from the edge towards the centre of the vineyard block after hydrophobic particle films and mussel shells were applied (experiment 3 ) have been analysed using generalised linear mixed effect models. In those models, the interaction between treatments and the position in the row in which adult sampling was performed (first, second, third and fourth bays), were considered as fixed effects, while the row in which those bays occurred was treated as a nested random effect (bays within a row) (Fig. 2b). A negative binomial error family was used to correct overdispersion (Zuur et al. 2009). A Wald test with a $\chi^{2}$ distribution was used to assess the significance of the treatments and the position in the row where beetle samples were taken (Bolker et al. 2009). These models were performed using the R packages "MASS", "Matrix", "Lme4" and "Aod". All statistical analyses were calculated using the software R v.3.2.5 (R Core Team 2016).

\section{Results and discussion}

\subsection{Changes in adult beetle behaviour by feeding and landing deterrents}

During 2014, the addition of mussel shells in the under-vine areas significantly reduced the number of adult $C$. zealandica that landed on those vines by $69 \%(t=-9.46 ; d f=14$; $p<0.001)$. In control plots, the mean number of adults was 189 adults bay ${ }^{-1}$, while on vines treated with mussel shells, these were 59 adults bay ${ }^{-1}$. In 2015, adult numbers on mussel shells $(t=3.32, d f=7, p<0.05)$ and on hydrophobic particle films combined with mussel shells $(t=5.26, d f=7, p<0.01)$ treated vines were statistically fewer than control. However, no differences were found between hydrophobic particle films and control $(t=0.37, d f=7, p=0.71)$, nor between mussel shells and both treatments combined (kaolin and shells) at the $5 \%$ significant level $(t=2.28, d f=7, p=0.06)$. The mean number of adults per bay was $56.5,54,27.5$ and 16 , for control, hydrophobic particle films, mussel shells and both combined, respectively. Adult $C$. zealandica began its flight 20 min after sunset, from 20:31 on November 6, until 20:39 on November 10. This behaviour stopped between 20:57 and 21:06 over the studied dates, respectively, with a mean flight time of $26 \mathrm{~min}$ each day. Adult hovering activity (beetles $\mathrm{min}^{-1}$ ) was lower over mussel-shell-treated plants, $10(t=3.49 ; d f=4 ; p<0.05)$ and $15 \min (t=3.29 ; d f=4$; $p<0.05$ ) after adult flight activity started (Fig. 3a). Landing activity was also lower in the mussel shells treatment, 10 $(t=2.76 ; d f=4 ; p=0.051), 15(t=5.22 ; d f=4 ; p<0.01)$, $20(t=4.51 ; d f=4 ; p<0.05)$ and $25 \min (t=4.4 ; d f=3$; $p<0.05$ ) after adult flight activity started (Fig. 3b).

Host location by insects is strongly influenced by olfactory and visual stimuli (Prokopy and Owens 1983; Foster and Harris 1997; Gurr et al. 2017). In the current work, the distinct smell emanating from the plots with mussel shells was anecdotally perceived some kilometres away from them; therefore, it is likely that such volatiles were also present on the control treatments. Thus, a potential mechanism behind the differences in adult numbers between mussel shells and control treatments was associated with changes in the visual perception of the plant host by adult $C$. zealandica. It has been previously suggested that $C$. zealandica females fly towards plant silhouettes against the sky (Farrell and Wightman 1972; González-Chang et al. 2017). If these silhouettes are produced by the contrast between the ultraviolet-B light coming from the sky and from the ground (Mellor and Hamilton 2003), it is possible that the reflective properties of mussel shells (Sandler et al. 2009; Creasy and Ross 2010) can "erase" the plant silhouettes from females' visual perception, confounding those with a portion of the sky. Therefore, a reduction in female numbers on the vines will further reduce the number of males arriving, as females attract males by releasing their sexual 
Fig. 3 Beetle behaviour on control (upper line) and treated vines with mussel shells (bottom line) at Wither Hills (2015). a Flying/hovering C. zealandica activity. b C. zealandica landing activity. Statistical differences between treatments at each time interval are presented $(* p<0.05$; $* * p<0.01)$. Error bars are two standard errors
Beetle behaviour on vines treated with mussel shells

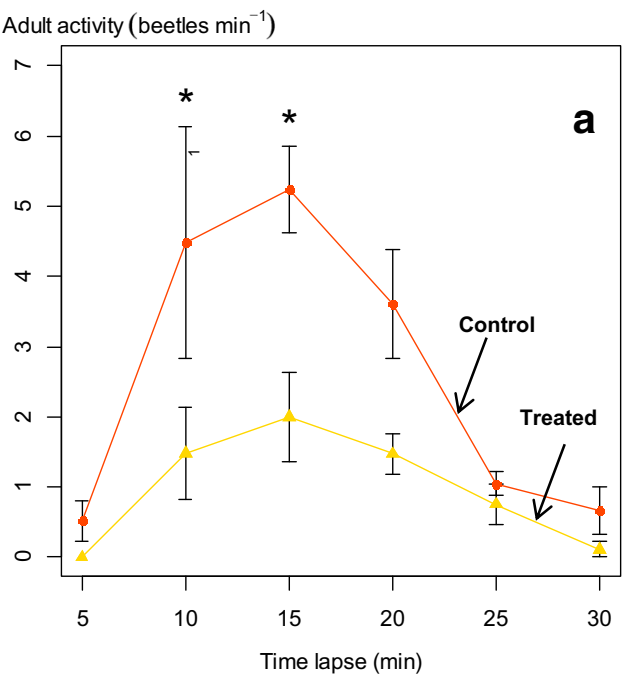

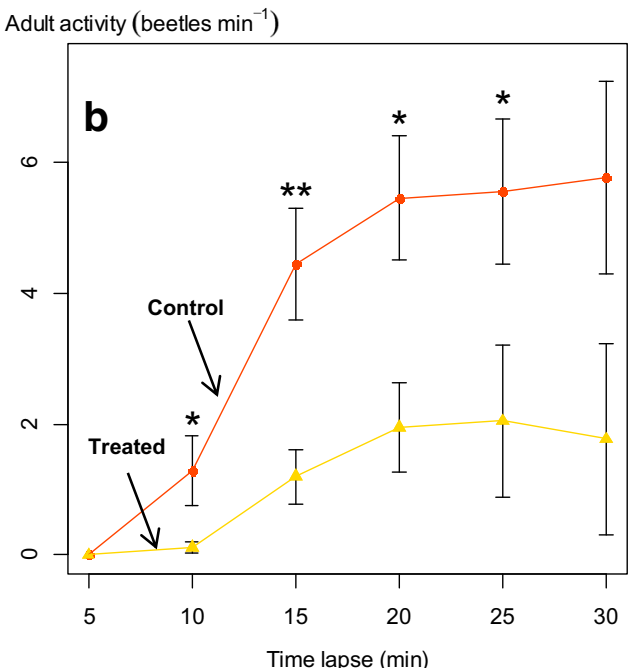

pheromone, phenol (Marshall et al. 2016). In a recent work, C. zealandica sex ratio of adults that land on vine plants was female-biased during the beginning of their daily flight activity, highlighting the importance of females in adult C. zealandica invasion dynamics in vineyards (GonzálezChang et al. 2017). Although ultraviolet-B light at dusk is not intense, it has been suggested that its relative intensity present in the sky compared with that coming from the ground is extremely high (Mellor and Hamilton 2003). This light contrast might be enough for dusk-flying insects' visual orientation and navigation behaviour.

\subsection{Adult beetle distribution within treated vineyard block}

The number of adults that landed along the vine rows (from vineyard's edge to $30 \mathrm{~m}$ from it) was significantly affected by the treatments applied $\left(\chi^{2}=42.7 ; d f=3 ; p<0.001\right)$. In addition, there was a significant interaction between treatments and the number of adults collected in the different bays along the vine rows $\left(\chi^{2}=40.2 ; d f=3 ; p<0.001\right)$. When treatments with mussel shells were present (mussel shells and hydrophobic particle films with shells combined), the mean number of adults was 21.7 and 44 adults bay ${ }^{-1}$, in the first and fourth bays, respectively. Conversely, in control and hydrophobic particle film treatments, the mean number of adults was 55.3 and 29.8 adults bay ${ }^{-1}$, in the first and fourth bays, respectively (Fig. 4). In a previous non-manipulative study, adult $C$. zealandica numbers were higher at the ends of vine rows (first bay), decreasing gradually along the vine row towards the centre of the block ( 8 th bay) (González-Chang 2016). The current work demonstrates that mussel shells applied at the edge of the vineyard block reduced the number of adults there but increased its numbers towards the centre of the block (Fig. 4). This change in beetles' distributional patterns might have implications for larval densities and adult damage distribution within vineyard blocks, as landing sites were previously related with oviposition sites within this species (González-Chang 2016); therefore, this behavioural change needs further

\section{Adult distribution amongst treatments}

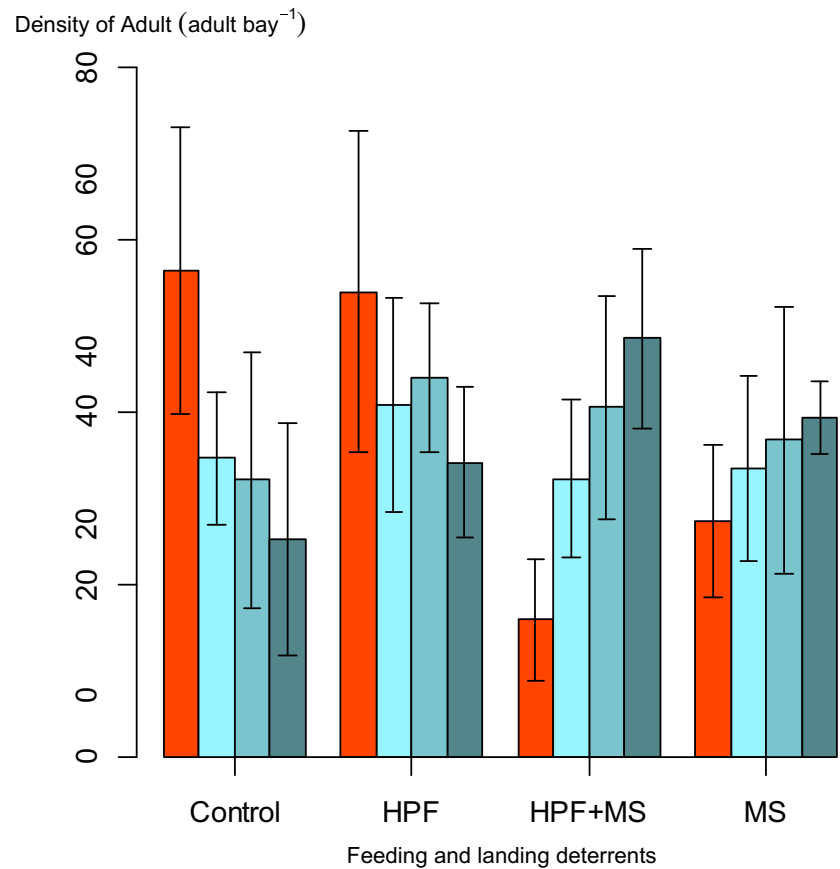

Fig. 4 Hydrophobic particle films (HPFs) as a feeding deterrent and mussel shells (MSs) as a landing deterrent effect on adult $C$. zealandica distribution along vine rows, evaluated in experiment 3 at Wither Hills (2015). Different bars within treatments (HPF, MS, HPF + MS, control), represent adult numbers in the different bays (a group of four vine plants) along the vine row, where adult insects were collected. On each treatment, bars from the left to the right show the first, second, third and fourth bays, respectively. The interaction between those treatments and the bay's position along the row was significant $\left(\chi^{2}=40.2 ; d f=3 ; p<0.001\right)$. Error bars are two standard errors 
investigation. Attention should focus on the number of bays (or rows) that need to be treated in order to deter adults from landing further into the block.

\subsection{Feeding and landing deterrents impact on plant damage and grape yield}

During 2014, feeding deterrents statistically reduced damage caused by adult $C$. zealandica compared to control $\left(F_{3,20}=7.98 ; p<0.01\right)$. However, no differences were found between the feeding deterrent treatments used $(p>0.8)$ (Fig. 5a). In experiment 1, the application of these deterrents reduced damage by $46 \%$. When the potential additive effect of hydrophobic particle films and mussel shells was evaluated in 2015, a significant damage reduction was also found $\left(F_{3,28}=31.9 ; p<0.001\right)$. Thus, a 33 and $73 \%$ damage reduction was achieved by hydrophobic particle films and mussel shells, respectively (Fig. 5b). The combination of both treatments on vine damage was not statistically different from the application of mussel shells alone $(p=0.9)$. Grape yield was significantly increased $\left(F_{3,28}=3.12 ; p<0.05\right)$ from 3 to $4.2 \mathrm{~kg} \mathrm{plant}^{-1}$ when mussel shells were present, leading to a $28 \%$ increase in grape yield. No differences were found when hydrophobic particle films was applied alone $(p=0.5)$, nor between mussel shells and both treatments combined $(p=0.9)$ on grape yield. In vines, hydrophobic particle films and diatomaceous earths have previously been combined to control the vine cicada $P$. alhageos, producing a significant reduction on its egg numbers by $55 \%$, and subsequently, an increase on grape yield by $48 \%$ (Valizadeh et al. 2013). The latter result was attributed to the hydrophobic-mineral barrier produced by hydrophobic particle films on the leaf surface, which limited the ability of $P$. alhageos to recognise its host, reducing the amount of eggs laid by this pest. However, in the present study, no significant differences were found when hydrophobic particle films and diatomaceous earths were mixed compared with their application alone, suggesting that the presence of this physical barrier might not be the mechanism behind $C$. zealandica damage reduction, as diatomaceous earths do not produce such a barrier (Korunic 2013). Previous studies have suggested that hydrophobic particle film efficacy might also be based on altering insect visual perception of its host plant, reducing the numbers that land on them (Showler 2002; Glenn and Puterka 2005; Silva and Ramalho 2013). However, in this work, the number of adult C. zealandica on plants treated with hydrophobic particle films was not different from control. Considering that both feeding deterrents' particles attach to insect's body parts (Ebeling 1971; Glenn and Puterka 2005), C. zealandica adults might attempt to remove them, thereby reducing their movement on vine leaves (Glenn et al. 1999). Also, plant palatability could be decreased by the presence of silicon-based particles (Massey et al. 2006). Furthermore, it has been suggested that hydrophobic particle films can obstruct insects'

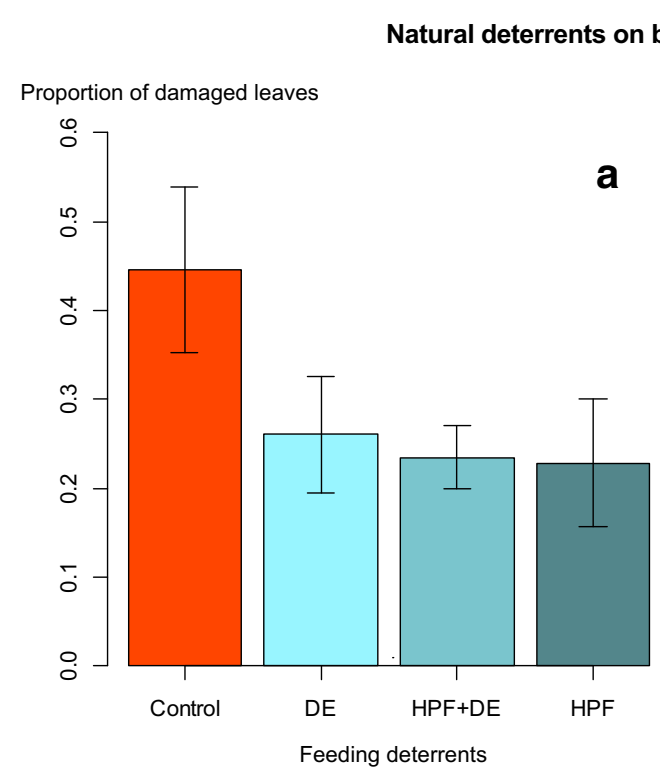

Fig. 5 Proportion of vine leaves damaged by C. zealandica adults when different natural deterrents were applied. a Data were obtained after experiment 1 was carried out in the Awatere Valley (2014). No statistical differences were found between the feeding deterrents diatomaceous earths (DEs), hydrophobic particle films (HPFs) and both treatments combined (HPF $+\mathrm{DE})(p>0.8)$. However, all deterrents were significantly different from control $\left(F_{3,20}=7.98 ; p<0.01\right)$. b Data

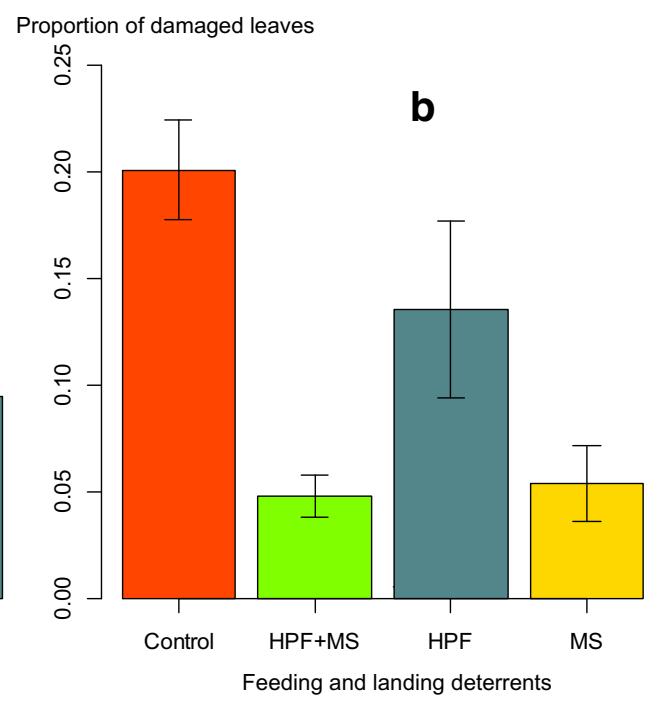

collected after experiment 3 was carried out in Whither Hills (2015). HPFs as a feeding deterrent, mussel shells (MSs) as a landing deterrent and both combined (HPF + MS) were statistically different from control $\left(F_{3,28}=31.9 ; p<0.001\right)$. No differences were found between both deterrent treatments combined (HPF + MS) and mussel shells alone (MS) $(p=0.9)$. Error bars are two standard errors 
digestive system (Showler 2002). It is therefore likely that a combination of these factors altered adult $C$. zealandica feeding behaviour after landed on vines.

Reflective mulches, such as plastic, aluminium, mussel shells and geotextile membranes have previously been tested to improve wine quality and increase grape yield (Hostetler et al. 2007; Sandler et al. 2009; Osrečak et al. 2016). In the USA, vines treated with mussel shells (cv. Chancellor) produced $5.56 \mathrm{~kg}_{\text {plant }}{ }^{-1}$ compared to $4.21 \mathrm{~kg}$ plant $^{-1}$ in control plots, which is a $32 \%$ increase in grape yield (Sandler et al. 2009). However, when vines treated with mussel shells (cv. Pinot Noir) were evaluated in New Zealand, no significant differences were observed in grape yield (Creasy and Ross 2010). Differential responses in grape yield might be related to the mollusc species used in those experiments, as Mercenaria mercenaria L. (Veneridae) was used in the USA, while Perna canaliculus Gmelin (Mytilidae) was used in New Zealand. It is likely that the different shell pigmentation between these two species affected the amount of photosynthetically active radiation reflected into the canopy (Sandler et al. 2009; Creasy and Ross 2010). This is in agreement with significant grape yield differences found in the USA (cv. Pinot Noir) when black geotextile membranes were compared to white geotextile membranes, producing 1.38 and $2.23 \mathrm{~kg} \mathrm{plant}^{-1}$, respectively (Hostetler et al. 2007).

In this work, the $28 \%$ increase in grape yield could be the expression of three different factors acting together, namely (i) insect damage reduction, (ii) ultraviolet-B effects on plant physiology and (iii) soil moisture increase. The dramatic $73 \%$ reduction in vine defoliation attributed to the "optical barrier" produced by the ultraviolet-B reflective properties of mussel shells on C. zealandica behaviour, probably increased vine-plant leaf area, which might have enhanced the photosynthetic production. Also, ultraviolet-B light can regulate the guard cells in leaf stomata, irreversibly closing or opening them (Jansen and van den Noort 2000). Leaf gas exchange increases, caused by stomatal opening might rise carbon dioxide absorption from the surrounding atmosphere, enhancing the overall amount of carbohydrates produced through photosynthesis (Roelfsema and Hedrich 2005). Also, the increased soil moisture previously found under vines treated with mussel shells (Sandler et al. 2009; Creasy and Ross 2010) could enhance the amount of water available to the vines, and thus improve grape yield. With a better understanding of the mechanisms behind the reflective and other properties of mussel shells on insect behaviour and plant physiology, this natural waste product could replace the use of plastic-derived mulches, especially considering the current high cost of biodegradable plastic mulches (Kasirajan and Ngouajio 2012). Similar economic constraints were reported when geotextile membrane mulches were used to enhance wine quality and grape yield (Hostetler et al. 2007). Conversely, mussel shells are inexpensive and easily available (where mussel farms are close) and would otherwise be disposed of in local landfills, with potential negative ecological and social consequences. In this context, mussel shells mulches might have a role as alternatives to enhance vineyard sustainability, and also have potential application for other horticultural crops that today rely heavily on plastic mulches for weed and pest control, moisture retention, crop yield increase and food quality enhancement.

\section{Conclusions}

The results presented here suggest that hydrophobic particle films, diatomaceous earths and mussel shells can be used as an ecologically sound strategy to reduce the damage caused by C. zealandica adults in vineyards. Furthermore, the application of mussel shells increased grape yield by $28 \%$, which was explained by behavioural changes in flying/hovering and landing patterns exhibited by this pest. Although the mechanisms behind this behavioural change and grape yield increase were not evaluated here, it was suggested that mussel shells' reflective properties in the ultraviolet-B light spectrum range might be responsible for these two phenomena. The effect of mussel shells on insect pest behaviour has never been reported before, so the results presented here open a new opportunity to recycle these shells, which will otherwise be disposed of in a local landfill. However, the effects of this treatment on insect behaviour need further investigation, as mussel shells deterrent effects on $C$. zealandica landing behaviour might lead to higher infestation rates in other parts of the vineyard if placed only at its edge.

Acknowledgements We gratefully acknowledge the field assistance provided by Coralline Houise, Jerry Nboyine, Mondo Kopua, Murray Trower, Ben Burridge and Chelsea Clarke. Thanks to New Zealand Winegrowers for partly funding the 2015 sampling season. We appreciate the comments of two anonymous reviewers that significantly improved this work.

Funding Information This research was done as part of M.G. Chang's $\mathrm{PhD}$ programme, funded by a Callaghan Innovation Scholarship (KNZLP1201) and Kono Beverages.

\section{References}

Antignus Y (2014) Management of air-borne viruses by "optical barriers" in protected agriculture and open-field crops. In: Loebenstein G, Katis N (eds) Advances in Virus Research. Academic PressElsevier, USA, p 1-33

Athanassiou CG, Kavallieratos NG, Vayias BJ, Tomanovic Z, Petrovic A, Rozman V, Adler C, Korunic Z, Milovanovic D (2011) Laboratory evaluation of diatomaceous earth deposits mined from several locations in central and southeastern Europe as potential protectants against coleopteran grain pests. Crop Prot 30:329-339. https://doi. org/10.1016/j.cropro.2010.10.004

Bolker BM, Brooks ME, Clark CJ, Geange SW, Poulsen JR, Stevens MH, White J-SS (2009) Generalized linear mixed models: a 
practical guide for ecology and evolution. Trends Ecol Evol 24:127135. https://doi.org/10.1016/j.tree.2008.10.008

Creasy GL, Ross O (2010) Reflective mulch effects on the grapevine environment, Pinot Noir vine performance, and juice and wine characteristics. Christchurch. New Zealand

Ebeling W (1971) Sorptive dusts for pest control. Annu Rev Entomol 16: 123-158. https://doi.org/10.1146/annurev.en.16.010171.001011

Farrell JAK, Wightman JA (1972) Observations on flight and feeding activity of adult Costelytra zealandica (White) (Col.,Scarabaeidae) in Nelson province. N Z J Agric Res 15:893-903. https://doi.org/10. 1080/00288233.1972.10421644

Foster SP, Harris MO (1997) Behavioral manipulation methods for insect pest-management. Annu Rev Entomol 42:123-146. https://oi.org/ 10.1146/annurev.ento.42.1.123

Glenn DM, Puterka GJ (2005) Particle films: a new technology for agriculture. Hortic Rev (Am Soc Hortic Sci) 31:1-44

Glenn DM, Puterka GJ, Vanderzwet T, Byers RE, Feldhake C (1999) Hydrophobic particle films: a new paradigm for suppression of arthropod pests and plant diseases. J Econ Entomol 92:759-771

González-Chang M (2016) Sustainable management of adult Costelytra zealandica (Coleoptera: Melolonthinae) damage in Marlborough vineyards. PhD Thesis. Lincoln University

González-Chang M, Boyer S, Lefort M-C, Nboyine J, Wratten SD (2017) Ecological and pest-management implications of sex differences in scarab landing patterns on grape vines. PeerJ 5:e3213. https://doi. org/10.7717/peerj.3213

Gurr G, Wratten SD, Landis DA, You M (2017) Habitat management to suppress pest populations: progress and prospects. Annu Rev Entomol 62:91-109. https://doi.org/10.1146/annurev-ento-031616035050

Hostetler GL, Merwin IA, Brown MG, Padilla-Zakour O (2007) Influence of undervine floor management on weed competition, vine nutrition, and yields of Pinot Noir. Am J Enol Vitic 58:421-430

Jansen MAK, van den Noort RE (2000) Ultraviolet-B radiation induces complex alterations in stomatal behaviour. Physiol Plant 110:189194. https://doi.org/10.1034/j.1399-3054.2000.110207.x

Kasirajan S, Ngouajio M (2012) Polyethylene and biodegradable mulches for agricultural applications: a review. Agron Sustain Dev 32:501-529. https://doi.org/10.1007/s13593-011-0068-3

Korunic Z (1998) Diatomaceous earths, a group of natural insecticides. J Stored Prod Res 34:87-97

Korunic Z (2013) Diatomaceous earths: natural insecticides. Pestic i fitomedicina 28:77-95. https://doi.org/10.2298/PIF1302077K

Marshall DG, Jackson TA, Unelius CR, Wee SL, Young SD, Townsend RJ, Suckling DM (2016) Morganella morganii bacteria produces phenol as the sex pheromone of the New Zealand grass grub from tyrosine in the colleterial gland. Sci Nat 103:59. https://doi.org/10. 1007/s00114-016-1380-1

Massey FP, Ennos AR, Hartley SE (2006) Silica in grasses as a defence against insect herbivores: contrasting effects on folivores and a phloem feeder. J Anim Ecol 75:595-603. https://doi.org/10.1111/j.13652656.2006.01082.x

Mellor HE, Hamilton JGC (2003) Navigation of Lutzomyia longipalpis (Diptera: Psychodidae) under dusk or starlight conditions. Bull Entomol Res 93:315-322. https://doi.org/10.1079/BER2003248

Osrečak M, Karoglan M, Kozina B (2016) Influence of leaf removal and reflective mulch on phenolic composition of Merlot, Teran and Plavac mali wines (Vitis vinifera L.) Sci Hortic (Amsterdam) 209: 261-269. https://doi.org/10.1016/j.scienta.2016.07.005

Prokopy RJ, Owens ED (1983) Visual detection of plants by herbivorous insects. Annu Rev Entomol 28:337-364. https://doi.org/10.1146/ annurev.en.28.010183.002005

R Core Team (2016) R: A language and environment for statistical computing. R Foundation for Statistical Computing. Vienna, Austria

Roelfsema MRG, Hedrich R (2005) In the light of stomatal opening: new insights into "the Watergate". New Phytol 167:665-691. https://doi. org/10.1111/j.1469-8137.2005.01460.x

Sandler HA, Brock PE II, Vanden Heuvel JE (2009) Effects of three reflective mulches on yield and fruit composition of coastal New England winegrapes. Am J Enol Vitic 60:332-338

Schindelin J, Arganda-Carreras I, Frise E, Kaynig V, Longair M, Pietzsch T, Preibisch S, Rueden C, Saalfeld S, Schmid B, Tinevez JY, White DJ, Hartenstein V, Eliceiri K, Tomancak P, Cardona A (2012) Fiji: an open-source platform for biological-image analysis. Nat Methods 9:676-682. https://doi.org/10.1038/nmeth.2019

Showler AT (2002) Effects of kaolin-based particle film application on boll weevil (Coleoptera: Curculionidae) injury to cotton. J Econ Entomol 95:754-762

Silva CAD, Ramalho FS (2013) Kaolin spraying protects cotton plants against damages by boll weevil Anthonomus grandis Boheman (Coleoptera: Curculionidae). J Pest Sci 86:563-569. https://doi. org/10.1007/s10340-013-0483-0

Valizadeh H, Abbasipour H, Farazmand H, Askarianzadeh A (2013) Evaluation of kaolin application on oviposition control of the vine cicada, Psalmocharias alhageos in vineyards (Homoptera: Cicadidae). Entomol Gen 34:279-286. https://doi.org/10.1127/ entom.gen/34/2013/279

Zuur AF, Ieno EN, Walker NJ, Saveliev AA, Smith GM (2009) Mixed effects models and extensions in ecology with R. Springer Science+ Business Media, Inc., New York 